\title{
Quantitative Determination of the Selectivities of Five Different Phenyl Radicals in Hydrogen Atom Abstraction from Ethanol
}

\author{
Linhong Jing, Leonard P. Guler, John J. Nash, and Hilkka I. Kenttämaa \\ Department of Chemistry, Purdue University, West Lafayette, Indiana, USA
}

\begin{abstract}
An experimental method is described for obtaining quantitative selectivity information for $\mathrm{H}$-atom abstraction by organic radicals from different sites of a substrate in the gas phase. The method is used to determine the selectivities of five different phenyl radicals toward the three different types of hydrogen atoms in ethanol. This experimental method involves studying the reactivities and selectivities of derivatives of the radicals that contain a chemically inert, charged group (distonic ions), which allows them to be manipulated in a Fourier-transform ion cyclotron resonance (FT-ICR) mass spectrometer. (J Am Soc Mass Spectrom 2004, 15, 913-919) @ 2004 American Society for Mass Spectrometry
\end{abstract}

$\Lambda$ large number of studies suggest that the action of some potential anti-tumor antibiotics is based on $\mathrm{H}$-atom abstraction by aromatic, $\sigma, \sigma$-biradical intermediates from a sugar moiety in DNA (which ultimately leads to cell death) [1-9]. These compounds, however, are also destructive to healthy cells. An understanding of the factors that control the selectivity of aryl monoradicals and biradicals in $\mathrm{H}$-atom abstraction reactions could aid the development of drugs that are more selective and, thus, less cytotoxic [10]. Here, we report the results for the first of a series of gas-phase studies on the selectivity of aryl radicals in H-atom abstraction reactions.

An examination of $\mathrm{H}$ - versus D-atom abstraction from a partially labeled substrate by a phenyl radical yields semi-quantitative information about the selectivity of the radical. The difficulty, however, is that the selectivity observed in such reactions does not exactly correspond to the selectivity that is observed for the same site in an unlabeled compound. If a kinetic isotope effect (KIE) exists, the presence of a heavy isotope can affect the relative abundances of the products. That is, D-atom abstraction is likely to be slower, relative to $\mathrm{H}$-atom abstraction, from the same site in the same molecule. Thus, in order to use the results obtained from selectivity studies of reactions of deuterium labeled compounds to understand the selectivities of the reactions of unlabeled analogs, it is necessary to develop a method that accounts for any potential KIE.

Dunlop and Tully have previously reported a method for obtaining site-specific rate constants for $\mathrm{H}$-atom abstraction by $\mathrm{HO} \cdot$ from 2-propanol in the gas

Published online May 10, 2004

Address reprint requests to Dr. H. I. Kenttämaa, Department of Chemistry, Purdue University, 1393 Brown Building, West Lafayette, IN 47907-1393, USA. E-mail: hilkka@purdue.edu phase by using a laser photolysis/laser-induced fluorescence technique [11]. However, this approach is based on the assumption that the KIE measured for $\mathrm{HO}$. for abstraction of a primary (methyl) H-/D-atom from ethane, or neopentane, represents the relative reactivity of $\mathrm{HO} \cdot$ toward $\mathrm{CH}_{3}$ - and $\mathrm{CD}_{3}$ - groups in 2-propanol. Herein, we report an approach that can be used to obtain quantitative selectivity information for radicals in $\mathrm{H}$-atom abstraction reactions that involve partially deuterium-labeled substrates without the assumption made by Dunlop and Tully, and the application of this method for the determination of the selectivities of five substituted phenyl radicals toward the three different types of hydrogen atoms in ethanol. Our method is based on the "distonic ion approach", which can be used to study radical reactions in the gas phase [12]. This experimental method involves studying the reactivities and selectivities of derivatives of the radicals which contain a chemically-inert, charged group (distonic ions), which allows them to be manipulated in a Fourier-transform ion cyclotron resonance (FT-ICR) mass spectrometer. The products of the $\mathrm{H}$ - and D-atom abstraction reactions can be easily identified in a mass spectrum by their different mass-to-charge ratios.

\section{Experimental}

All experiments were carried out using a dual-cell Finnigan Model FTMS 2001 FT-ICR mass spectrometer described previously [13]. Unlabeled ethanol (chemical purity $99.5 \%$ ), and three partially labeled forms of ethanol, $\mathrm{CD}_{3} \mathrm{CH}_{2} \mathrm{OH}$ (isotopic purity: 99.0 atom\% D; chemical purity: $99.9 \%$ ), $\mathrm{CH}_{3} \mathrm{CD}_{2} \mathrm{OH}$ (isotopic purity: 99.4 atom\% D; chemical purity: $99.4 \%$ ) and $\mathrm{CD}_{3} \mathrm{CD}_{2} \mathrm{OH}$ (isotopic purity: 99.5 atom\% D; chemical purity: $99.9 \%$ ), $\mathrm{CH}_{3} \mathrm{CD}_{2} \mathrm{OH}$ (isotopic purity: 99.4 atom\% D; chemical 
Table 1. Total Reaction Efficiencies ${ }^{\mathrm{a}, \mathrm{b}}$ (EFF) and Branching Ratios ${ }^{\mathrm{b}, \mathrm{c}}$ for H/D-Atom Abstraction from Ethanol by Several Charged Phenyl Radicals

\begin{tabular}{|c|c|c|c|c|c|}
\hline & $\mathbf{a}$ & b & c & d & e \\
\hline $\mathrm{EFF}_{\mathrm{CH} 3 \mathrm{CH} 2 \mathrm{OH}}$ & $11 \pm 1 \%$ & $8.2 \pm 1.8 \%$ & $4.5 \pm 0.7 \%$ & $0.38 \pm 0.06 \%$ & $0.30 \pm 0.03 \%$ \\
\hline $\begin{array}{l}\text { Branching } \\
\text { ratio }(H / D)\end{array}$ & $\begin{array}{l}100 \% / \\
0 \%\end{array}$ & $\begin{array}{l}100 \% / \\
0 \%\end{array}$ & $\begin{array}{l}100 \% / \\
0 \%\end{array}$ & $\begin{array}{l}100 \% / \\
0 \%\end{array}$ & $\begin{array}{l}100 \% / \\
0 \%\end{array}$ \\
\hline $\mathrm{EFF}_{\mathrm{CD} 3 \mathrm{CH} 2 \mathrm{OH}}$ & $9.4 \pm 0.2 \%$ & $7.8 \pm 0.1 \%$ & $4.4 \pm 0.2 \%$ & $0.39 \pm 0.05 \%$ & $0.30 \pm 0.03 \%$ \\
\hline $\begin{array}{l}\text { Branching } \\
\text { ratio }(H / D)\end{array}$ & $\begin{array}{l}91.2 \pm 0.2 \% / \\
8.8 \pm 0.2 \%\end{array}$ & $\begin{array}{l}89 \pm 1 \% / \\
11 \pm 1 \%\end{array}$ & $\begin{array}{l}94.8 \pm 0.5 \% / \\
5.2 \pm 0.5 \%\end{array}$ & $\begin{array}{l}98.0 \pm 0.2 \% / \\
2.0 \pm 0.2 \%\end{array}$ & $\begin{array}{l}98.3 \pm 0.3 \% / \\
1.7 \pm 0.3 \%\end{array}$ \\
\hline $\mathrm{EFF}_{\mathrm{CH} 3 \mathrm{CD} 2 \mathrm{OH}}$ & $8.0 \pm 0.8 \%$ & $5.0 \pm 0.9 \%$ & $2.8 \pm 0.4 \%$ & $0.15 \pm 0.02 \%$ & $0.14 \pm 0.02 \%$ \\
\hline $\begin{array}{l}\text { Branching } \\
\text { ratio }(H / D)\end{array}$ & $\begin{array}{l}44 \pm 1 \% / \\
56 \pm 1 \%\end{array}$ & $\begin{array}{l}40 \pm 1 \% / \\
60 \pm 1 \%\end{array}$ & $\begin{array}{l}40 \pm 1 \% / \\
60 \pm 1 \%\end{array}$ & $\begin{array}{l}45 \pm 5 \% / \\
55 \pm 5 \%\end{array}$ & $\begin{array}{l}24 \pm 4 \% / \\
76 \pm 4 \%\end{array}$ \\
\hline $\mathrm{EFF}_{\mathrm{CD} 3 \mathrm{CD} 2 \mathrm{OH}}$ & $5.9 \pm 1.1 \%$ & $4.8 \pm 0.6 \%$ & $2.2 \pm 0.3 \%$ & $0.12 \pm 0.02 \%$ & $0.12 \pm 0.01 \%$ \\
\hline $\begin{array}{l}\text { Branching } \\
\text { ratio }(H / D)\end{array}$ & $\begin{array}{l}1.2 \pm 0.3 \% / \\
98.8 \pm 0.3 \%\end{array}$ & $\begin{array}{l}1.7 \pm 0.3 \% / \\
98.3 \pm 0.3 \%\end{array}$ & $\begin{array}{l}3.5 \pm 1.2 \% / \\
96.5 \pm 1.2 \%\end{array}$ & $\begin{array}{l}11 \pm 1 \% / \\
89 \pm 1 \%\end{array}$ & $\begin{array}{l}6.1 \pm 1.5 \% / \\
93.9 \pm 1.5 \%\end{array}$ \\
\hline
\end{tabular}

a Percentage of collisions that leads to products \pm standard deviation determined from at least three separate measurements.

b The stated uncertainties are \pm one standard deviation.

c Percentage of $\mathrm{H}$-atom abstraction products/percentage of $\mathrm{D}$-atom abstraction products.

purity: $99.4 \%$ ) and $\mathrm{CD}_{3} \mathrm{CD}_{2} \mathrm{OH}$ (isotopic purity: 99.5 atom\% D; chemical purity: $99.9 \%$ ), were purchased from Isotec, Inc., Sigma-Aldrich, and used as received. The chemical purities, and the absence of any partially labeled isotopomers, were confirmed via mass spectrometric analyses of these materials. The aryl radicals were generated and isolated, and their reactivities were then studied, as described previously [12, 13]. All reactions were monitored until at least $90 \%$ of the radical had reacted. Reaction efficiencies (EFF) were derived by dividing the experimental second-order reaction rate constants by the calculated [14] collision rate constants $\left(\mathrm{k}_{\text {exp }} / \mathrm{k}_{\text {coll }}\right)$. The product branching ratios were determined by dividing the abundance of each product ion by the sum of the abundances for all of the product ions.

\section{Results and Discussion}

Based on previous reactivity studies [13] for a variety of charged phenyl radicals, five substituted phenyl radicals, whose reactivities toward ethanol were expected to range from relatively high (Table $1 \mathrm{a}, \mathrm{b}$, and c) to relatively low (Table 1e and f), were chosen for this study. Ethanol (both unlabeled and partially deuterium labeled) was selected as the $\mathrm{H}$-atom donor because it contains hydrogen atoms that have similar (structural) environments to those in sugars, and because $\mathrm{H}$-atom transfer was expected to be the dominant, if not the only, pathway for the reactions with the selected phenyl radicals.

The total reaction efficiencies and H/D branching ratios for the reactions of the phenyl radicals with ethanol are shown in Table 1. Hydrogen atom abstraction was indeed the only observed reaction. As expected, the combined $\mathrm{H}$ - and D-atom abstraction efficiencies are lower for most of the reactions with partially labeled ethanol than the corresponding $\mathrm{H}$-atom abstraction efficiencies for the reactions with unlabeled ethanol. Clearly, a KIE exists for these reactions. The KIE includes a primary effect (associated with $\mathrm{C}-\mathrm{D}$ versus $\mathrm{C}-\mathrm{H}$ bond being broken) 
and two kinds of secondary effects, $\alpha$-secondary isotope effects due to the difference in the residual isotopic composition at the carbon atom undergoing $\mathrm{C}-\mathrm{H} / \mathrm{C}-\mathrm{D}$ bond cleavage, and $\beta$-secondary isotope effects arising from isotopic substitution in an adjacent group. In order to obtain $\mathrm{H}$-atom abstraction rates for the different sites in $\mathrm{CH}_{3} \mathrm{CH}_{2} \mathrm{OH}$, it was necessary to assume that the $\beta$-secondary isotope effects are either absent, or make an insignificant contribution to the overall reaction efficiency. This assumption seems reasonable considering the fact that secondary isotope effects, and in particular $\beta$-secondary isotope effects, are typically close to unity, and hence much smaller than primary isotope effects [15]. Support for this expectation is provided by a rough approximation of the $\beta$-secondary isotope effects using the experimental data reported here. The $\beta$-secondary isotope effects were estimated to be close to unity (0.83-0.99) by solving the seven equations shown below. It was assumed that the $\beta$-secondary isotope effect $(\mathrm{x})$ for $\mathrm{H}$-abstraction from the $\mathrm{CH}_{3}$ group in $\mathrm{CH}_{3} \mathrm{CD}_{2} \mathrm{OH}$ is equal to that for $\mathrm{H}$-abstraction from the $\mathrm{CH}_{2}$ group in $\mathrm{CD}_{3} \mathrm{CH}_{2} \mathrm{OH}$, and the $\beta$-secondary isotope effect (y) for $D$-abstraction from the $\mathrm{CD}_{3}$ group in $\mathrm{CD}_{3} \mathrm{CD}_{2} \mathrm{OH}$ is equal to that for D-abstraction from the $\mathrm{CD}_{2}$ group in $\mathrm{CD}_{3} \mathrm{CD}_{2} \mathrm{OH}$.

$$
\begin{aligned}
& \mathrm{EFF}_{\mathrm{CH} 3 \mathrm{CH} 2 \mathrm{OH}}=\mathrm{EFF}_{\mathrm{CH} 3}+\mathrm{EFF}_{\mathrm{CH} 2}+\mathrm{EFF}_{\mathrm{OH}} \\
& \mathrm{EFF}_{\mathrm{CD} 3 \mathrm{CH} 2 \mathrm{OH}}=\mathrm{EFF}_{\mathrm{CD} 3}+\frac{\mathrm{EFF}_{\mathrm{CH} 2}}{\mathrm{x}}+\mathrm{EFF}_{\mathrm{OH}} \\
& E F F_{\mathrm{CH} 3 \mathrm{CD} 2 \mathrm{OH}}=\frac{E F F_{\mathrm{CH} 3}}{\mathrm{x}}+E F F_{\mathrm{CD} 2}+E F F_{\mathrm{OH}}
\end{aligned}
$$

$$
\mathrm{EFF}_{\mathrm{CD} 3 \mathrm{CD} 2 \mathrm{OH}}=\frac{\mathrm{EFF}_{\mathrm{CD} 3}}{\mathrm{y}}+\frac{\mathrm{EFF}_{\mathrm{CD} 2}}{\mathrm{y}}+\mathrm{EFF}_{\mathrm{OH}}
$$

$$
\begin{aligned}
& \frac{\mathrm{EFF}_{\mathrm{CH} 2}}{\mathrm{x}}+\mathrm{EFF}_{\mathrm{OH}} \\
& =\frac{\mathrm{EFF}}{\mathrm{CD} 3} \text { abstraction branching ratio from } \mathrm{CD}_{3} \mathrm{CH}_{2} \mathrm{OH} \\
& \mathrm{D}-\text { abstraction branching ratio from } \mathrm{CD}_{3} \mathrm{CH}_{2} \mathrm{OH}
\end{aligned}
$$

$$
\begin{aligned}
& \frac{\mathrm{EFF}_{\mathrm{CD} 2}}{\frac{\mathrm{EFF}}{\mathrm{CH} 3}+\mathrm{EFF}_{\mathrm{OH}}} \\
& =\frac{\mathrm{D}-\text { abstraction branching ratio from } \mathrm{CH}_{3} \mathrm{CD}_{2} \mathrm{OH}}{\mathrm{H}-\text { abstraction branching ratio from } \mathrm{CH}_{3} \mathrm{CD}_{2} \mathrm{OH}}
\end{aligned}
$$

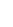

$$
\begin{aligned}
& \frac{\mathrm{EFF}_{\mathrm{CD} 3}}{\mathrm{y}}+\frac{\mathrm{EFF}_{\mathrm{CD} 2}}{\mathrm{y}} \\
& =\frac{\mathrm{EFF}}{\mathrm{OH}}-\text { abstraction branching ratio from } \mathrm{CD}_{3} \mathrm{CD}_{2} \mathrm{OH} \\
& \mathrm{H}-\text { abstraction branching ratio from } \mathrm{CD}_{3} \mathrm{CD}_{2} \mathrm{OH}
\end{aligned}
$$

This assumption is required in order to equate the rate of $\mathrm{H}$-atom abstraction from a specific group, such as $\mathrm{CH}_{3^{-}}, \mathrm{CH}_{2^{-}}$, or $\mathrm{HO}-$, in a partially labeled compound to that in an unlabeled compound.

The total efficiency for H- (or D-) atom abstraction from a molecule (such as ethanol) is equal to the sum of the reaction efficiencies for $\mathrm{H}$ - (or D-) atom abstraction from each of the possible reactive sites (hereafter, referred to as "group efficiencies"):

$$
\begin{aligned}
& \mathrm{EFF}_{\mathrm{CH} 3 \mathrm{CH} 2 \mathrm{OH}}=\mathrm{EFF}_{\mathrm{CH} 3}+\mathrm{EFF}_{\mathrm{CH} 2}+\mathrm{EFF}_{\mathrm{OH}} \\
& \mathrm{EFF}_{\mathrm{CD} 3 \mathrm{CH} 2 \mathrm{OH}}=\mathrm{EFF}_{\mathrm{CD} 3}+\mathrm{EFF}_{\mathrm{CH} 2}+\mathrm{EFF}_{\mathrm{OH}} \\
& \mathrm{EFF}_{\mathrm{CH} 3 \mathrm{CD} 2 \mathrm{OH}}=\mathrm{EFF}_{\mathrm{CH} 3}+\mathrm{EFF}_{\mathrm{CD} 2}+\mathrm{EFF}_{\mathrm{OH}} \\
& \mathrm{EFF}_{\mathrm{CD} 3 \mathrm{CD} 2 \mathrm{OH}}=\mathrm{EFF}_{\mathrm{CD} 3}+\mathrm{EFF}_{\mathrm{CD} 2}+\mathrm{EFF}_{\mathrm{OH}}
\end{aligned}
$$

where $\mathrm{EFF}_{\mathrm{CH} 3 \mathrm{CH} 2 \mathrm{OH}}, \mathrm{EFF}_{\mathrm{CD} 3 \mathrm{CH} 2 \mathrm{OH}}, \mathrm{EFF}_{\mathrm{CH} 3 \mathrm{CD} 2 \mathrm{OH}}$, and $\mathrm{EFF}_{\mathrm{CD} 3 \mathrm{CD} 2 \mathrm{OH}}$ are the measured reaction efficiencies (total, for both $\mathrm{H}$ - and D-atom abstraction) for $\mathrm{CH}_{3} \mathrm{CH}_{2} \mathrm{OH}, \quad \mathrm{CD}_{3} \mathrm{CH}_{2} \mathrm{OH}, \mathrm{CH}_{3} \mathrm{CD}_{2} \mathrm{OH}$, and $\mathrm{CD}_{3} \mathrm{CD}_{2} \mathrm{OH}$, respectively, and $\mathrm{EFF}_{\mathrm{CH} 3}, \mathrm{EFF}_{\mathrm{CH} 2}, \mathrm{EFF}_{\mathrm{OH}}$, $\mathrm{EFF}_{\mathrm{CD} 3}$, and $\mathrm{EFF}_{\mathrm{CD} 2}$ are the reaction group efficiencies for $\mathrm{H}$ - or D-atom abstraction from each group $\left(\mathrm{CH}_{3}^{-}\right.$, $\mathrm{CH}_{2^{-}}, \mathrm{HO}-, \mathrm{CD}_{3^{-}}$, and $\mathrm{CD}_{2^{-}}$, respectively) without statistical corrections.

In order to derive the group efficiencies, the above equations, as well as three additional independent equations (see below), were employed.

$$
\begin{aligned}
& \left(\mathrm{EFF}_{\mathrm{CH} 2}+\mathrm{EFF}_{\mathrm{OH}}\right) / \mathrm{EFF}_{\mathrm{CD} 3} \\
& =\mathrm{H} / \mathrm{D} \text {-branching ratio for } \mathrm{CD}_{3} \mathrm{CH}_{2} \mathrm{OH} \\
& \mathrm{EFF}_{\mathrm{CD} 2} /\left(\mathrm{EFF}_{\mathrm{CH} 3}+\mathrm{EFF}_{\mathrm{OH}}\right) \\
& =\mathrm{D} / \mathrm{H} \text {-branching ratio for } \mathrm{CH}_{3} \mathrm{CD}_{2} \mathrm{OH} \\
& \left(\mathrm{EFF}_{\mathrm{CD} 3}+\mathrm{EFF}_{\mathrm{CD} 2}\right) / \mathrm{EFF}_{\mathrm{OH}} \\
& =\mathrm{D} / \mathrm{H} \text {-branching ratio for } \mathrm{CD}_{3} \mathrm{CD}_{2} \mathrm{OH}
\end{aligned}
$$

The least squares method (implementation by MatLab 6.5) was used to obtain the best possible solutions to this over-determined system (seven equations, five unknowns) [16].

The $\mathrm{CH}_{3}-, \mathrm{CH}_{2}-$, and $\mathrm{HO}$-group efficiencies for the five phenyl radicals are shown in Table 2. The accuracy 
Table 2. Group Efficiencies, Contribution Ratios, Selectivities and Total Reaction Efficiencies for H-Atom Abstraction from Ethanol by Several Charged Phenyl Radicals ${ }^{\mathrm{a}}$

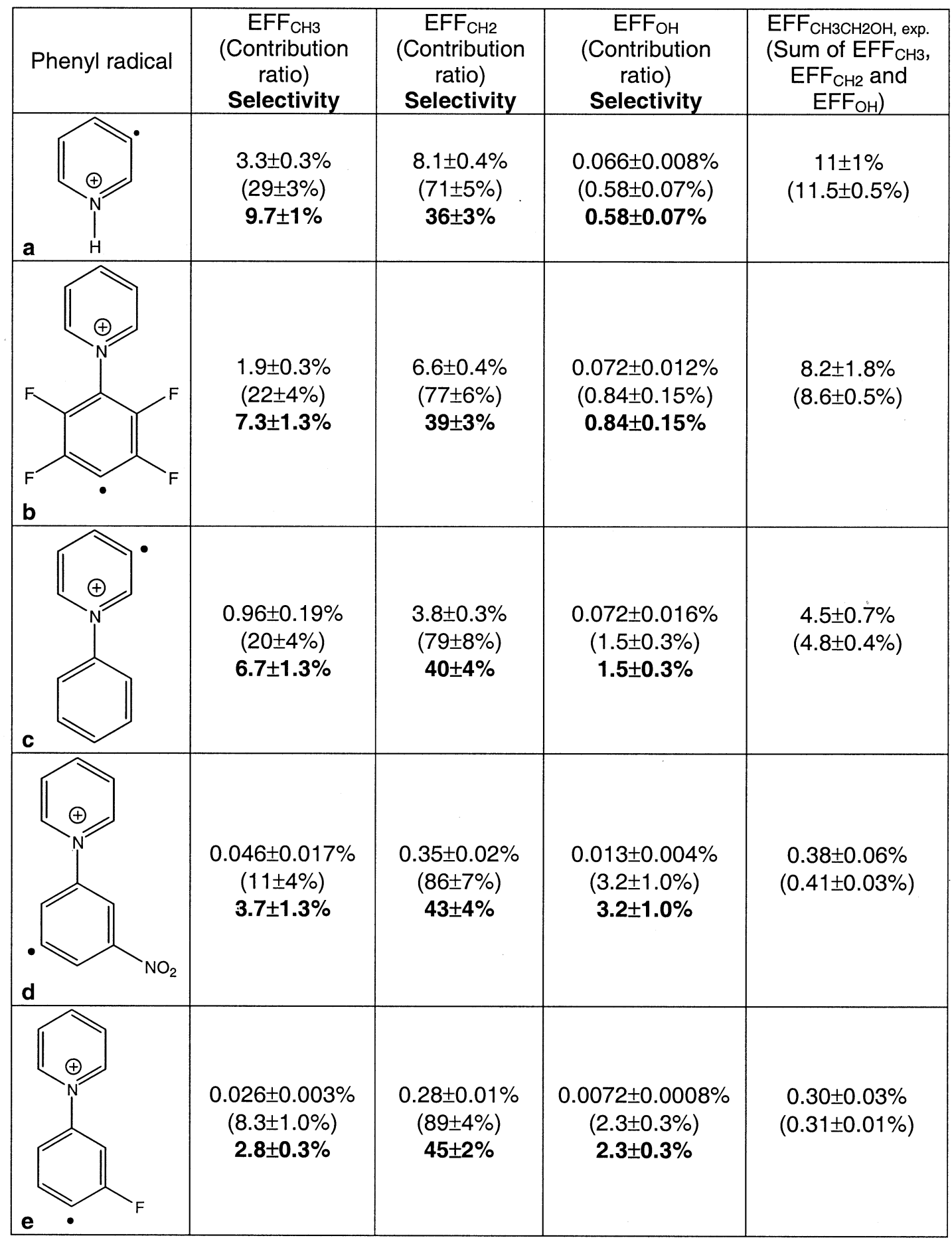

${ }^{\text {a }}$ The stated uncertainties are \pm one standard deviation.

and legitimacy of the method was evaluated by comparing the measured total reaction efficiency for each phenyl radical to the sum of the derived group efficiencies. For all five phenyl radicals, the sum of the derived group efficiencies are indeed the same as the measured total reaction efficiencies, within experimental error (Table 2).
In order to evaluate the percentage that each group contributes to the total $\mathrm{H}$-atom abstraction efficiency in unlabeled ethanol, a "contribution ratio" was calculated for each group. To do this, each $\mathrm{CH}_{3^{-}}, \mathrm{CH}_{2^{-}}$, or HOgroup efficiency (calculated as described above) was divided by the sum of the group efficiencies. For example, the $\mathrm{CH}_{3}-, \mathrm{CH}_{2}$-, and $\mathrm{HO}$ - group efficiencies for 
Table 3. Calculated Kinetic Isotope Effects (mixed primary and $\alpha$-secondary kinetic isotope effects) for H/D-Atom Abstraction from the Methylene and Methyl Groups in Ethanol ${ }^{\mathrm{a}}$

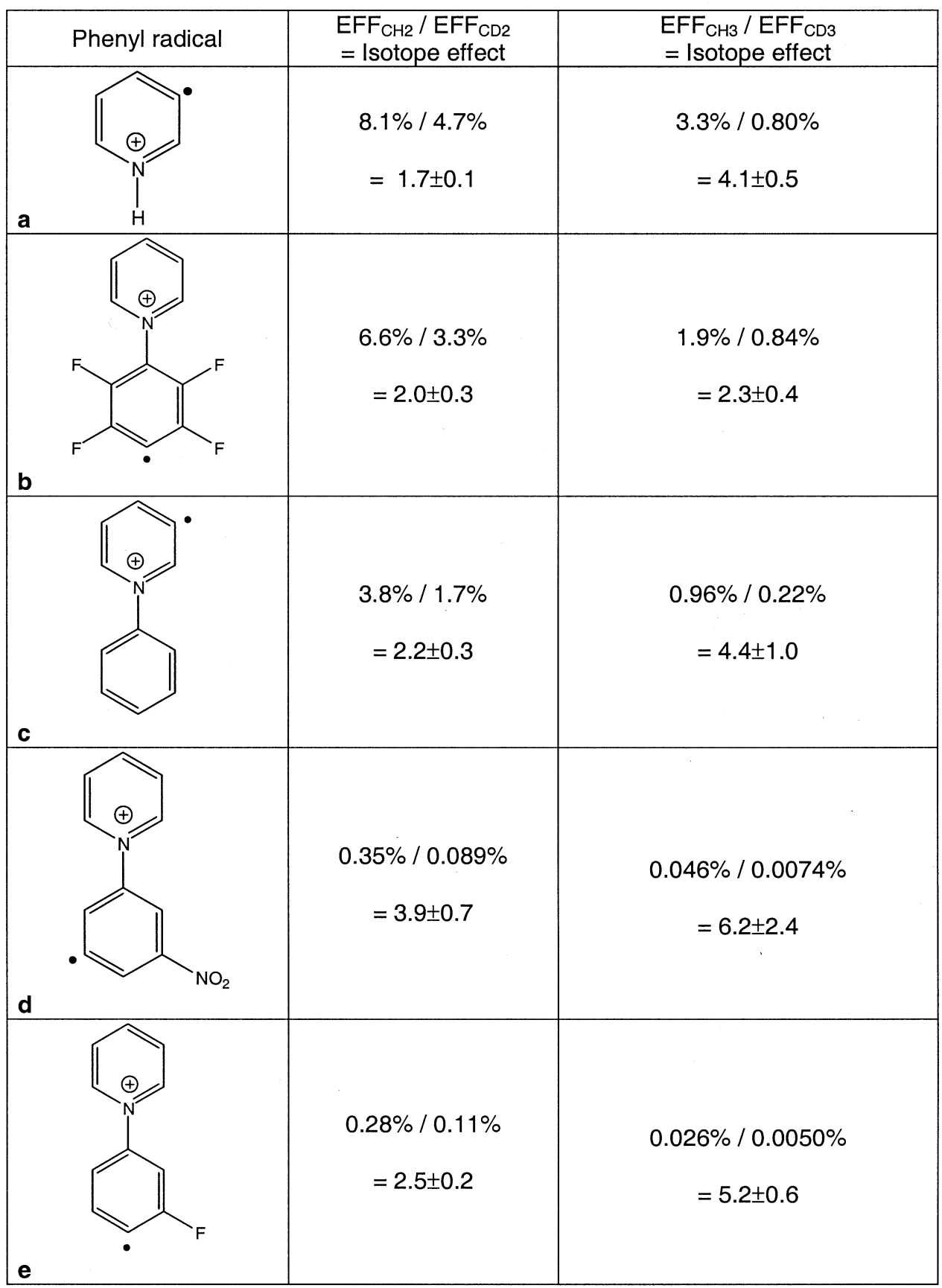

a The stated uncertainties are \pm one standard deviation.

phenyl radical a are $3.3 \%, 8.1 \%$ and $0.066 \%$, respectively (Table 2). Dividing each of these group efficiencies by the sum of the group efficiencies $(3.3 \%+8.1 \%$ $+0.066 \%=11.5 \%$ ) yields contribution ratios of $29 \%$, $71 \%$, and $0.58 \%$ for the $\mathrm{CH}_{3}{ }^{-}, \mathrm{CH}_{2^{-}}$, and HO-groups, respectively. Finally, the "selectivity" for $\mathrm{H}$-atom abstraction from each group was obtained by dividing each contribution ratio by the number of $\mathrm{H}$ atoms contained in that particular group. For phenyl radical a, the calculated selectivities for $\mathrm{H}$-atom abstraction from the $\mathrm{CH}_{3}-\mathrm{CH}_{2^{-}}$, and $\mathrm{HO}$-groups are $9.7 \%(29 \%$ / $3), 36 \%(71 \% / 2)$, and $0.58 \%(0.58 \% / 1)$, respectively. Thus, phenyl radical a is about four times more reactive toward the $\mathrm{CH}_{2}$-group in ethanol than toward the $\mathrm{CH}_{3}$-group, and is least reactive toward the HO-group. Comparison of the selectivities of all the phenyl radicals suggests that as the reactivity of the radical decreases $(\mathbf{a}>\mathbf{b}>\mathbf{c}>\mathbf{d}>\mathbf{e})$, the selectivity toward the $\mathrm{CH}_{2}$-group increases slightly $(36 \%, 39 \%$, $40 \%, 43 \%$, and $45 \%$, respectively) while the selectivity 


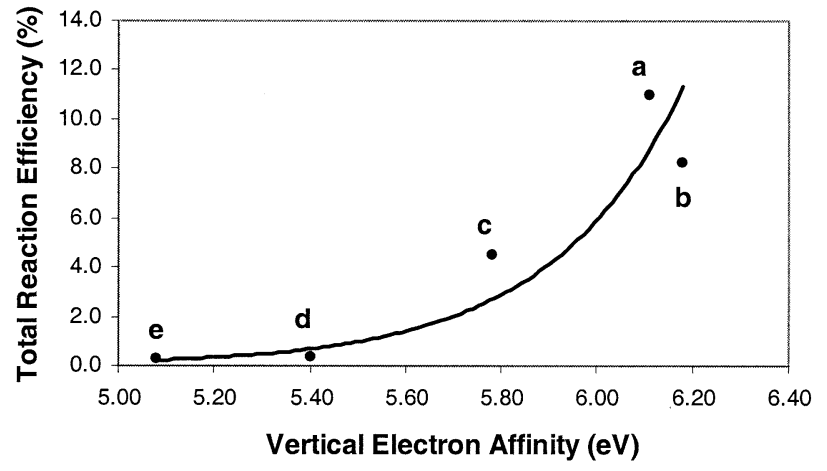

Figure 1. Total reaction efficiency for $\mathrm{H}$-atom abstraction from ethanol versus calculated (B3LYP/6-31 + G(d)) vertical electron affinity. Note that the reaction efficiency for $\mathrm{H}$-atom abstraction increases as the vertical electron affinity of the phenyl radical increases. The calculated electron affinities for (a)-(e) are: $6.11 \mathrm{eV}$, $6.18 \mathrm{eV}, 5.78 \mathrm{eV}, 5.40 \mathrm{eV}$, and $5.08 \mathrm{eV}$, respectively.

toward the $\mathrm{CH}_{3}$-group decreases $(9.7 \%, 7.3 \%, 6.7 \%$, $3.7 \%$, and $2.8 \%$, respectively).

The contribution ratios and selectivities for all five phenyl radicals are given in Table 2. It is perhaps not surprising that all five phenyl radicals are most reactive toward the $\mathrm{CH}_{2}$ - group in ethanol considering the fact that the homolytic bond dissociation energy (298 K) for the $\mathrm{CH}_{2}$-group $(94.5 \pm 0.9 \mathrm{kcal} / \mathrm{mol}$, [17]) is lower than that for either the HO-group (104.7 $\pm 0.8 \mathrm{kcal} / \mathrm{mol},[17])$ or the $\mathrm{CH}_{3}$-group $(99.5 \pm 2 \mathrm{kcal} / \mathrm{mol}[18])$.

The kinetic isotope effects for H/D-atom abstraction from the methylene and methyl groups in ethanol by the phenyl radicals, which are composed of the primary and $\alpha$-secondary kinetic isotope effects, were calculated by taking the ratios of the group efficiencies, $\mathrm{EFF}_{\mathrm{CH} 2}$ / $\mathrm{EFF}_{\mathrm{CD} 2}$ and $\mathrm{EFF}_{\mathrm{CH} 3} / \mathrm{EFF}_{\mathrm{CD} 3}$, respectively, and are listed in Table 3. The kinetic isotope effect for $\mathrm{H} / \mathrm{D}$-atom abstraction from the methylene group by the five phenyl radicals ranges from 1.7 to 3.9 , and that from the methyl group ranges from 2.3 to 6.2.

Finally, differences in the atom abstraction efficiencies of substituted phenyl radicals have been rationalized [13] based on differences in the extent of stabilization of relevant transition states due to polarization. In addition, the (calculated) vertical electron affinities (EA) of these radicals were found [13] to correlate well with the observed reaction efficiencies, which suggest that the EA may provide a measure of the extent of stabilization in the transition state. The vertical EAs for a-e were calculated at the B3LYP/6-31 + G(d) level of theory (the appropriateness of this level of theory has been addressed previously [13]). Indeed a weak correlation was found between the measured total reaction efficiencies for radicals a-e and the calculated vertical EAs (Figure 1).

\section{Conclusions}

The experimental determination of the selectivities of five charged phenyl radicals toward the three different types of hydrogen atoms in unlabeled ethanol indicate that, like $\mathrm{HO} \cdot$ radical $[7,19]$, there is a strong preference for $\mathrm{H}$-atom abstraction from the $\mathrm{CH}_{2}$-group in ethanol by all of the phenyl radicals. In addition, the preference (selectivity) for the $\mathrm{CH}_{2}$-group increases and that for the $\mathrm{CH}_{3}$-group decreases as the reactivity (and electrophilicity) of the phenyl radical decreases. The preference for $\mathrm{H}$-atom abstraction from the $\mathrm{CH}_{2}$-group in ethanol by the phenyl radicals is undoubtedly due to the lower bond dissociation energy for this group than that for either the $\mathrm{CH}_{3}$-group or the $\mathrm{HO}$-group.

The kinetic isotope effect KIE that has been reported [20] for D-atom abstraction by $\mathrm{HO}$ - from the $\mathrm{CD}_{3}$-group in methanol $(2.15$ at $293.5 \mathrm{~K})$ falls within the range of KIE values measured for D-atom abstraction by the five phenyl radicals from the $\mathrm{CD}_{2}$-group in ethanol (1.7-3.9). The KIE that has been reported [21] for D-atom abstraction by $\mathrm{HO}$. from the $\mathrm{CD}_{3}$-group in ethane (4.61 at 293 $\mathrm{K})$ is also within the range of the KIE measured for D-atom abstraction from the $\mathrm{CD}_{3}$-group in ethanol by the five phenyl radicals (2.3-6.2).

\section{Acknowledgments}

The authors thank the National Institutes of Health for providing financial support for this work. They also thank Seung-Hyun Anna Lee for her assistance with several of the experiments, and Jason Price and Chris Petzold for helpful discussions.

\section{References}

1. Stubbe, J.; Kozarich, J. W.; Wu, W.; Vanderwall, D. E. Bleomycins: A Structural Model for Specificity, Binding, and Double Strand Cleavage. Acc. Chem. Res. 1996, 29, 322-330.

2. Miaskiewicz, K.; Osman, R. Theoretical Study on the Deoxyribose Radicals Formed by Hydrogen Abstraction. J. Am. Chem. Soc. 1994, 116, 232-238.

3. Bothe, E. G.; Görner, H.; Opitz, J.; Schulte-Frohlinde, D.; Siddiqi, A.; Wala, M. Single- and Double-Strand Break Formation in Double-stranded DNA upon Nanosecond LaserInduced Photoionization. Photochem. Photobiol. 1990, 52, 949959.

4. Cerutti, P. A. Prooxidant States and Tumor Promotion. Science 1985, 227, 375-381.

5. Meunier, B.; Pratviel, G.; Bernadou, J. Active Species Involved in Oxidative DNA Cleavage. Bull. Soc. Chim. Fr. 1994, 131, 933-943.

6. Nicolaou, K. C.; Dai, W. M. Chemistry and Biology of the Enediyne Anticancer Antibiotics. Angew. Chem. 1991, 30, 13871416.

7. Pardo, L.; Banfelder, J. R.; Osman, R. Theoretical Studies of the Kinetics, Thermochemistry, and Mechanism of H-Abstraction from Methanol and Ethanol. J. Am. Soc. 1992, 114, 2382-2390.

8. Pratviel, G.; Bernadou, J.; Meunier, B. Carbon-Hydrogen Bonds of DNA Sugar Units as Targets for Chemical Nucleases and Drugs. Angew. Chem. Int. Ed. Engl. 1995, 34, 746-769.

9. Steenken, S. Purine Bases, Nucleosides, and Nucleotides: Aqueous Solution Redox Chemistry and Transformation Reactions of Their Radical Cations and $\mathrm{e}^{-}$and $\mathrm{OH}$ Adducts. Chem. Rev. 1989, 89, 503-520.

10. Hoffner, J.; Schottelius, M. J.; Feichtinger, D.; Chen, P. Chemistry of the 2,5-Didehydropyridine Biradical: Computational, 
Kinetic, and Trapping Studies Toward Drug Design. J. Am. Chem. Soc. 1998, 120, 376-385.

11. Dunlop, J. R.; Tully, F. P. Catalytic Dehydration of Alcohols by OH. 2-Propanol: An Intermediate Case. J. Phys. Chem. 1993, 97, 6457-6464.

12. Thoen, K. K.; Smith, R. L.; Nousiainen, J. J.; Nelson, E. D.; Kenttämaa, H. I. Charged Phenyl Radicals. J. Am. Chem. Soc. 1996, 118, 8669-8676.

13. (a) Heidbrink, J. L.; Thoen, K. K.; Kenttämaa, H. I. Polar Effect on Iodine Atom Abstraction by Charged Phenyl Radicals. J. Org. Chem. 2000, 65, 645-651. (b) Heidbrink, J. L.; RamírezArizmendi, L.; Thoen, K. K.; Guler, L.; Kenttämaa, H. I. Polar Effects Control Hydrogen-Abstraction Reactions of Charged, Substituted Phenyl Radicals. J. Phys. Chem. A 2001, 105, 7875-7884. (c) Heidbrink, J. L.; Amegayibor, F. S.; Kenttämaa, H. I. Gas-Phase Radical-Radical Recombination Reactions of Nitroxides with Substituted Phenyl Radicals, unpublished.

14. Su, T.; Chesnavich, W. J. Parameterization of the Ion-Polar Molecule Collision Rate Constant by Trajectory Calculations. J. Chem. Phys. 1982, 76, 5183-5185.

15. (a) Isaacs, N. S. Physical Organic Chemistry; Longman Scientific \& Technical: Harlow, Essex, England, 1987, Wiley: New York, pp 256-268. (b) Lowry, T. H.; Richardson, K. S. Mechanism and Theory in Organic Chemistry, 2nd ed.; Harper \& Row Publishers: New York, 1981, pp 233-240. (c) Tschuikow-Roux, E.; Niedzielski, J. Secondary Kinetic Isotope Effects in Hydrogen and Deuterium Abstraction by Chlorine Atoms from the Chloromethyl Group in Gaseous Ethyl Chlorides: Effects of Isotope Substitution in the Adjacent Methyl Group. J. Photo- chem 1984, 27, 141-161. (d) Niedzielski, J.; Tschuikow-Roux, E. Yano, T. Hydrogen/Deuterium Abstraction by Chlorine Atoms from Gaseous Ethyl Chlorides. Secondary Kinetic Isotope Effects in the System $\mathrm{CH} 3 \mathrm{CH} 2 \mathrm{Cl}, \mathrm{CH} 3 \mathrm{CHDCl}, \mathrm{CH} 3 \mathrm{CD} 2 \mathrm{Cl}$. Int. J. Chem. Kinet. 1984, 16, 621-631. (e) Niedzielski, J.; Tschuikow-Roux, E. Secondary Kinetic Isotope Effects: Deuterium Abstraction by Chlorine Atoms from the $\mathrm{CD}_{3}$ Group in $\mathrm{CD} 3 \mathrm{CH} 2 \mathrm{Cl}, \mathrm{CD} 3 \mathrm{CHDCl}, \mathrm{CD} 3 \mathrm{CD} 2 \mathrm{Cl}$. Chem. Phys. Lett. 1984, $105,527-530$.

16. (a) Strang, G. Introduction to Applied Mathematics; Wellesley: Cambridge, 1986, p 398. (b) Graybill, F. Theory and Application of the Linear Model; Duxbury Press: 1976, p 207.

17. (a) Dyke, J. M.; Groves, A. P.; Lee, E. P. F.; Zamanpour Niavaran, M. H. Study of the $\mathrm{CH}_{3} \mathrm{CHOH}$ Radical with Ultraviolet Photoelectron Spectroscopy. J. Phys. Chem. A 1997, 101, 373-376. (b) Ervin, K. M.; De Turi, V. F. Anchoring the Gas-Phase Acidity Scale. J. Phys. Chem. A 2002, 106, 9947-9956.

18. Ruscic, B.; Berkowitz, J. The Heats of Formation of Some $\mathrm{C}_{2} \mathrm{H}_{5} \mathrm{O}^{+}$Isomers, Relevant Bond Energies in Ethanol, and PA $\left(\mathrm{CH}_{3} \mathrm{CHO}\right)$. J. Chem. Phys. 1994, 101, 10936-10946.

19. Asmus, K. D.; Mockel, H.; Henglein, A. Pulse Radiolytic Study of the Site of $\mathrm{OH}$. Radical Attack on Aliphatic Alcohols in Aqueous Solution. J. Phys. Chem. 1973, 77, 1218-1221.

20. Hess, W. P.; Tully, F. P. Hydrogen-Atom Abstraction from Methanol by OH. J. Phys. Chem. 1989, 93, 1944-1947.

21. Tully, F. P.; Droege, A. T.; Koszykowski, M. L.; Melius, C. F. Hydrogen-Atom Abstraction from Alkanes by OH. 2. Ethane. J. Phys. Chem. 1986, 90, 691-698. 